\title{
Composition, coagulation characteristics, and cheese making capacity of yak milk
}

\author{
Jian Zhang, ${ }^{1} \odot$ Ming Yang, ${ }^{1}$ Dongyan Cai, ${ }^{1}$ Yijiang Hao, ${ }^{1}$ Xiao Zhao, ${ }^{1}$ Yuanhua Zhu, ${ }^{1}$ Hong Zhu, ${ }^{2}$ \\ and Zhennai Yang ${ }^{1 *}$ (1) \\ ${ }^{1}$ Beijing Advanced Innovation Center for Food Nutrition and Human Health, Beijing Engineering and Technology Research Center \\ of Food Additives, Beijing Technology and Business University, China 100048 \\ ${ }^{2}$ Shijiazhuang Junlebao Dairy Industry Co. Ltd., China 050221
}

\section{ABSTRACT}

Yak is one of the few species of which the rennetcoagulated cheese making characteristics of its milk are still not well understood. This study investigated composition and rennet-induced coagulation properties of milk from 17 individual yak cows in comparison with milk from 32 individual Holstein cows. Yak cows produced milk with generally higher concentrations of milk components. The concentrations of fat, protein, solids-not-fat (SNF), and calcium in yak milk were 1.89-, 1.68-, 1.46-, and 2-fold those in Holstein milk, respectively. The hydrodynamic radii of casein micelles $(187.25 \mathrm{~nm})$ and chymosin-induced paracasein $(1,620 \mathrm{~nm})$ were about twice the sizes of those found in Holstein milk. Higher concentrations of calcium in yak milk, together with larger sizes of casein micelles, explains the reason for its fast rate of curd formation and firmer curd texture. Optical microrheology analysis also showed that $\mathrm{Ca}^{2+}$ concentration had greater influence on the coagulation of yak milk than on Holstein milk. Cheese making trials with yak and Holstein milk proved the higher cheese yield of yak milk: 1.67-fold that of Holstein milk. Therefore, yak milk could be a suitable source of milk for enzyme-coagulated cheese making.

Key words: yak milk, coagulation characteristics, cheese yield, Cheddar cheese

\section{INTRODUCTION}

Milk composition is a decisive factor for the yield and quality of dairy products (Murphy et al., 2016). To help their calves survive the harsh cold and anoxic conditions of their habitat, yak produce a milk with high content of dry matter (16.3 to $19.0 \%$ ), fat (5.6 to 8.8\%),

Received July 8, 2019.

Accepted October 29, 2019

*Corresponding author: yangzhennai@th.btbu.edu.cn and protein (4.68 to 5.41\%), and abundant nutrients compared with other species ( $\mathrm{Li}$ et al., 2011; Cui et al., 2016). From the perspective of cheese processing, milk with such high levels of dry matter is well suited for cheese making. Every year, more than 1.6 million tonnes of yak milk are produced in the southwest region of China, including the Qinghai, Gansu, Sichuan, and Tibet areas (Lin et al., 2018). However, little of the milk was processed into cheese due to the diet habits of local people, and the cheese making properties of yak milk have seldom been reported.

In terms of potential for cheese making, yak milk might have different coagulation properties and cheese yielding capacity than Holstein milk (Yang et al., 2014; Sun et al., 2018). Yak milk contains casein micelles of larger average size than Holstein casein micelles; thus, yak casein micelles aggregate more slowly than Holstein casein micelles (Zhang et al., 2017a). Furthermore, the average diameter of fat globules in yak milk was 4.39 $\mu \mathrm{m}$, twice that of Holstein milk fat (Luo et al., 2018). This might affect the cheese yield and moisture content, because fat globules of large size are prone to disruption during curd stirring, which decreases the rate of curd syneresis, resulting in more moisture retention after the curd pressing (Walstra et al., 2005). In support of this, elevated fat levels in the rennet coagulum added more than its own weight to the yield of cheese (Logan et al., 2017). In addition, the colloidal calcium phosphate content of yak milk, a driving force of coagulation, has also been found to be higher than that of Holstein cow milk $(19.90 \mathrm{mmol} / \mathrm{L}$ vs. $11.93 \mathrm{mmol} / \mathrm{L}$; Zhang et al., 2017a). Yak milk has been shown to form acid-induced gel at a higher $\mathrm{pH}$ (5.0 to 5.4) than that of Holstein milk (pH 4.8; Zhang et al., 2017a), but the enzymeinduced coagulation properties of yak milk have not been studied.

The objectives of this study were to compare the composition and coagulation properties of yak milk and Holstein cow milk, focusing on the effects of casein micelle size and calcium concentration on the milk co- 
agulation properties (MCP) and on the relationship between milk composition and coagulation properties. Cheddar cheeses were made with both of the milks to compare the yields and quality parameters of cheese, to test the potential of yak milk in cheese making.

\section{MATERIALS AND METHODS}

\section{Milk and Sample Collection}

Milk samples were collected from 17 yak cows (Bos grunniens var. Qinghai Plateau) and 32 Holstein cows for 3 sequential days in Qinghai province, China. The cows were on their second or third lactation cycles, and in the middle term of lactation, which was 2 to 4 milking months for the yak and 3 to 7 milking months for the Holstein. Milk from the afternoon and morning milkings was bulked to form a single daily sample for each Holstein cow, whereas yak cows were milked and sampled only once per day, in the morning. The collected milk samples were chilled and stored for subsequent analysis and cheese making.

\section{Raw Milk Composition Analysis}

Both yak and Holstein raw milk samples were analyzed for fat, protein, casein, and lactose, using a Foss milk analyzer (MilkoScan Minor, Foss Analytics, Hillerød, Denmark) calibrated before analysis. Concentrations of caseins ( $\beta$-casein, $\alpha$-casein, $\kappa$-casein, $\alpha$-lactalbumin, and $\beta$-lactoglobulin) were measured via electrophoresis, as reported by Manderson et al. (1998). Concentrations of $\mathrm{Ca}^{2+}$ and $\mathrm{Mg}^{2+}$ were measured using atomic absorption spectrophotometry, and concentrations of $\mathrm{Na}$ and $\mathrm{K}$ were determined via flame photometry.

\section{Cheese Making and Composition Analysis}

Cheddar cheeses were prepared according to standard procedures (Walstra et al., 2005), using a laboratory-scale trilateral cheese vat (Shanghai PRECISE Packaging Co. Ltd., Shanghai, China). For each species of milk, 3 batches of cheese were made. Each batch of cheese was made with $20 \mathrm{~L}$ of pasteurized milk, mesophilic starter (R704, CHR Hansen, Hørsholm, Denmark), and calf rennet (Chr. Hansen Stamix 1150) with milk-clotting strength of 1,150 international milkclotting units/g. Each batch of cheese was packed into 1.5- to 2.8-kg blocks and ripened at $6^{\circ} \mathrm{C}$ for $90 \mathrm{~d}$. Cheese samples taken at d 0,30,60, and 90 were grated and analyzed for salt, fat, protein, and moisture, as described by Hickey (Hickey et al., 2006; Or-Rashid et al., 2008; Zhang et al., 2013). The pH of a slurry, prepared by macerating $10 \mathrm{~g}$ of grated cheese with $12 \mathrm{~mL}$ of cold deionized water, was measured using a calibrated pH meter (FiveEasyPlus, Mettler Toledo, Greifensee, Switzerland).

\section{Determination of Milk Coagulation Property Using Optigraph}

The MCP of the samples was analyzed using the revised method of Kübarsepp (Hickey et al., 2006). Briefly, $0.5 \mathrm{~g}$ of chymosin powder (Stamix 1150, Chr. Hansen) was dissolved in $20 \mathrm{~mL}$ of water to prepare chymosin solution, then $20 \mu \mathrm{L}$ of chymosin solution was added to $10.0 \mathrm{~mL}$ of milk, to a final chymosin concentration of $0.05 \mathrm{mg} / \mathrm{mL}$. The mixtures were stirred for 15 to $20 \mathrm{~s}$ before analysis. MCP was analyzed using Optigraph (Ysebaert, Frepillon, France). The following parameters were determined from the displacement/ time output signal (Figure 1): RCT $=$ rennet coagulation time, the time at which the time/displacement signal begins to bifurcate at the onset of gelation; K20 $=$ time at which the bifurcated signal attains a width of $20 \mathrm{~mm}$; the reciprocal, $1 / \mathrm{K} 20$, is an index of curd firming rate; $\mathbf{A 6 0}=$ width of the bifurcation 60 min after rennet addition, an index of curd firmness (Zulewska et al., 2018).

\section{Determination of Casein Micellar and Paracasein Sizes by Dynamic Light Scattering}

For dynamic light-scattering (DLS) measurements, we used a light-scattering goniometer (ALV/CGS-3, ALV, Langen, Germany) with vertically polarized incident light of wavelength $632.8 \mathrm{~nm}$ from a He-Ne laser equipped with ALV/LSE-5004 light-scattering electronics and multiple tau digital correlators. Milk caseins were isolated and prepared according to the method described by Zhang et al., 2017a). The concentrations of casein in $0.01 \mathrm{M}$ of PBS were adjusted to 1.0, 1.5, and $2.0 \mathrm{~g} / \mathrm{L}$, respectively; then $50 \mathrm{mg} / \mathrm{L}$ chymosin was added to the mixture and shaken for $15 \mathrm{~s}$, to prepare the clear transparent solutions for examination. All DLS experiments were performed at scattering angle $90^{\circ}$, temperature $25^{\circ} \mathrm{C}$.

The normalized autocorrelation function $g^{(2)}(t)$ of scattered light intensity was measured and expressed in terms of the field autocorrelation function or in terms of the autocorrelation function of the concentration fluctuations $g^{(1)}(q, t)$ :

$$
g^{(2)}(q, t)=\frac{[I(q, 0) I(q, t)]}{[I(q, 0)]^{2}}=A+\beta\left|g^{(1)}(q, t)\right|^{2}
$$


where $g^{(2)}(q, t)$ is the autocorrelation function of intensity fluctuation of scattered light, $q$ is the scattering wave vector, $t$ is the delay time, $I$ is the intensity of scattering light, $A$ is the baseline, and $\beta$ is the coherent factor depending on the detection optics. For a broadly distributed relaxation, $|g(q, t)|$ is related to a characteristic relaxation time distribution $[G(\Gamma)]$ as follows:

$$
\left|g^{(1)}(q, t)\right|=\int_{0}^{\infty} G(\Gamma) \exp (-\Gamma t) d \Gamma
$$

According to equations [1] and $[2],[G(\Gamma)]$ can be deduced from the Laplace inversion of the $g^{(2)}(q, t)$ value by using a CONTIN analysis (Scotti et al., 2015); $\Gamma$ is the decay rate, $\exp (-\Gamma)$ stands for the exponential function of $-\Gamma$ with natural constant as base. From the Stokes-Einstein equation, hydrodynamic radius $R_{h}$ can be calculated thus (Lehmann et al., 2018):

$$
D_{C=0}=\left(\frac{\Gamma}{q^{2}}\right)_{q=0, c=0}=\frac{k_{B} T}{6 \pi \eta_{s} R_{h}},
$$

where $D_{C=0}$ is the translational diffusion coefficient $D$ at infinite dilution, $C$ is the concentration of EPS, $T$ is the absolute temperature, $k_{B}$ is the Boltzmann constant, and $\eta_{s}$ is the viscosity of solvent. In our study, both fast and slow relaxation modes were detected; thus the time autocorrelation function could be calculated by the sum of 2 relaxations (Buhler and Rinaudo, 2000):

$$
\begin{aligned}
& g^{(1)}(q, t)= \\
& \frac{\left[E_{\text {fast }}(q, t) E_{\text {fast }}^{*}\left(q, t^{\prime}+t\right)\right]+\left[E_{\text {slow }}(q, t) E_{\text {slow }}^{*}\left(q, t^{\prime}+t\right)\right]}{[I(q)]},
\end{aligned}
$$

$$
g^{(1)}(q, t)=A_{\text {fast }}(q) \exp \left(-\Gamma_{\text {fast }} t\right)+A_{\text {slow }}(q) \exp \left(-\Gamma_{\text {slow }} t\right),
$$

where $E_{\text {fast }}(q)$ and $E_{\text {slow }}(q)$ are the fast and the slow electric scattered fields, respectively; $E^{*}$ is the complex conjugate of $E ; t^{\prime}$ is the time lag of time $t ; \Gamma_{\text {fast }}$ and $\Gamma_{\text {slow }}$ are the corresponding relaxation times, respectively; $A_{\text {fast }}(q)$ and $A_{\text {slow }}(q)$ are the relative amplitudes, and $A_{\text {fast }}(q)+A_{\text {slow }}(q)=1$. We can analyze the scattering light intensity-intensity time correlation function $G^{(2)}(q, t)$ using methods previously described (Buhler and Rinaudo, 2000). The $G^{(2)}(\tau)$ outputs 2 average hydrodynamic radii, $\left(R_{h}\right)_{\text {fast }}$ and $\left(R_{h}\right)_{\text {slow }}$, using a double-exponential fit result or a CONTIN fit and the Stokes-Einstein equation result (Zhang et al., 2010); $\tau$ is the delay time.

\section{Effects of Calcium Concentration on Rheological Properties of Yak Milk Curd Measured by Optical Microrheometer}

Milk samples containing $0.015 \%$ (wt/wt), $0.02 \%$ (wt/wt), and $0.03 \%$ (wt/wt) $\mathrm{CaCl}_{2}$ were prepared and measured using the Microrheolaser Lab (Rheolaser Master, Formulation Inc., Toulouse, France), following the method described by Sandra et al. (2011). In brief, an aliquot of milk and chymosin mixture $(20 \mathrm{~mL})$ was filled in a glass cuvette, and the scattering parameters were measured over $60 \mathrm{~min}$ at $33^{\circ} \mathrm{C}$. Triplicate measurements were performed for each sample to detect Brownian motion of the particle as the droplet mean square displacement (MSD) versus time. Elasticity index and solid-liquid balance (SLB) parameters of the samples were obtained from the software RheoSoft Master 1.4.0.0 (Formulaction, Toulouse, France).

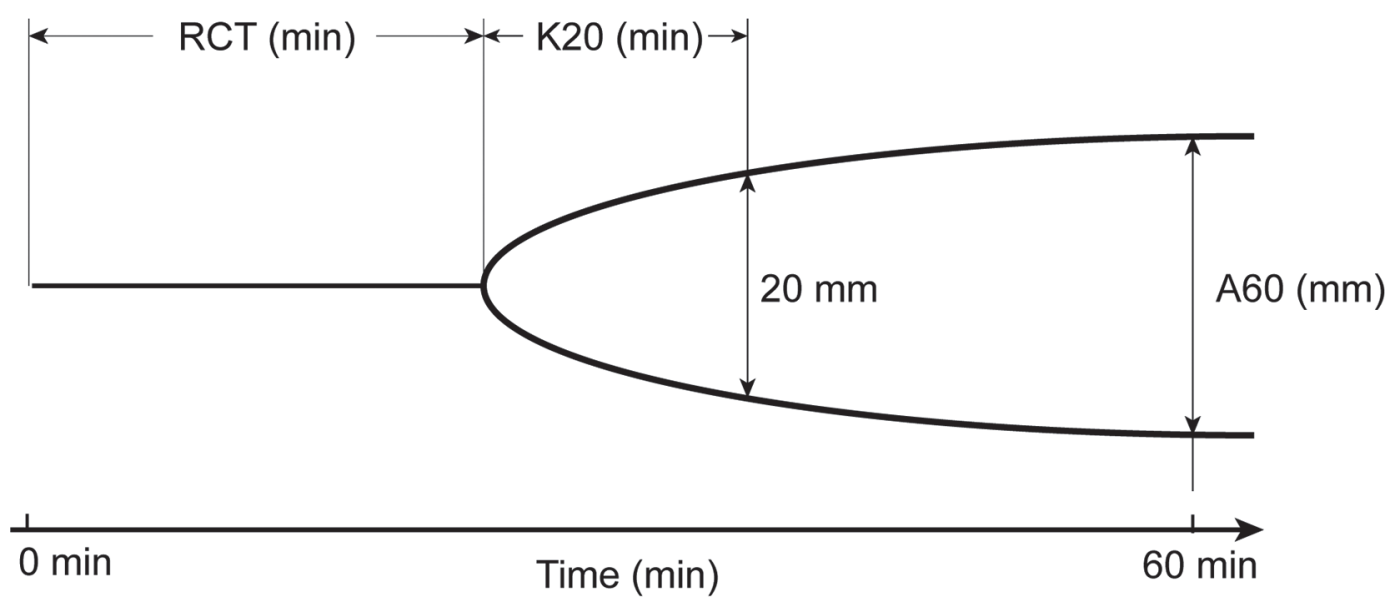

Figure 1. Illustrations of the coagulation parameters in Optigraph (Ysebaert, Frepillon, France), including rennet coagulation time (RCT), time at which the bifurcated signal attains a width of $20 \mathrm{~mm}$ (K20), and width of the bifurcation at 60 min after rennet addition (A60). 


\section{Cheese Texture Analysis}

Cheese samples were prepared and measured according to the method described by McCarthy et al. (2017). Briefly, the cheese was cut into cubes of $1 \mathrm{~cm}^{3}$. Triplicate cheese cubes from each group were compressed to $40 \%$ of their original height at a velocity of $1 \mathrm{~mm} / \mathrm{s}$, using a TA texture analyzer (TA-X2, Stable Micro Systems, Godalming, UK) equipped with a compression plate of $30-\mathrm{mm}$ diameter and fitted with a $10-\mathrm{kg}$ load cell. The hardness and fraction force were recorded. The flowability of cheese was measured in triplicate using the method described by McCarthy et al. (2016). Flowability was defined as the percent increase in mean diameter of the cheese disc.

\section{Microstructure of Cheese Observed via Cryoscanning Electron Microscopy}

Microstructure of cheese was observed via cryoscanning electron microscopy (cryo-SEM) using previously reported methods (Zhang et al., 2017b). In brief, the cheese samples were frozen in liquid nitrogen $\left(-210^{\circ} \mathrm{C}\right)$ and transferred into a vacuum chamber. Then the samples were cut to expose a fresh inner surface and coated with gold-palladium at $10 \mathrm{mV}$ for $90 \mathrm{~s}$. The specimen was then observed under a scanning electron microscope (S-3000N, Hitachi, Tokyo, Japan) at $3 \mathrm{kV}$.

\section{Statistical Analysis}

Differences among means from individual cows were analyzed using a one-way ANOVA with XLSTAT 2015 (Addinsoft Inc., Long Island, NY). Pearson correlations between the composition and coagulation properties were also analyzed using XLSTAT 2015. Normal distribution testing of data was performed using Origin 9.5 (Originlab Inc., Northampton, MA).

\section{RESULTS AND DISCUSSION}

\section{Composition and Coagulation Properties of Yak and Holstein Cow Milk}

The milk samples collected from 17 heads of yak and 32 heads of Holstein cows were analyzed for milk composition and coagulation properties as shown in Table 1. Yak cows produced milk with higher concentrations of fat, protein, and SNF, being 1.89-, 1.68-, and 1.46fold those of Holstein milk $(P<0.05)$, respectively. But yak $\kappa$-casein was $9 \%$ lower $(P<0.05)$, which has also been previously reported and which has been considered to be the reason for the slow coagulation speed of yak caseins (Zhang et al., 2017a). The mineral contents of the milk from the 2 species were significantly different, with the concentration of calcium in yak milk being nearly 2 -fold that of Holstein milk $(P<0.05)$. This also affected the coagulation properties of the milk (Akkerman et al., 2019).

To examine the effects of these compositional differences on milk coagulation properties, we analyzed the coagulation properties of yak and Holstein milk using Optigraph. As shown in Table 1, the RCT of yak milk (31.16 min) was longer than that of Holstein milk (28.49 min) due to lower concentration of $\kappa$-casein in yak milk, which decreases the rate of enzymatic hydrolysis of casein micelles to form chymosin-induced paracasein (Fox et al., 2017a). However, the rate of subsequent curd formation of yak milk (11.55 min) was faster than that of Holstein milk (12.67 min), indicating that the para-CN of yak milk aggregated to form a gel network more quickly than that of Holstein milk. This accorded with our finding that yak milk formed a firmer gel $(\mathrm{A} 60=53.56 \mathrm{~mm})$ than Holstein milk did $(\mathrm{A} 60=48.67 \mathrm{~mm})$. Variation in coagulation properties of milk from different bovine species have been reported, as between Holstein and Jersey (Auldist et al., 2004), Rendena (De Marchi et al., 2007), Brown Swiss (Stocco et al., 2017), Simmental (Bonfatti et al., 2016), and Alpine Grey (Zendri et al., 2017). Among these species, Jersey cattle have the closest relationship with

Table 1. Variation in concentrations of milk components, rennet coagulation time (RCT), rate of curd formation (K20), and curd firmness (A60) of milk samples from yak and Holstein cows (mean $\pm \mathrm{SD})$

\begin{tabular}{|c|c|c|}
\hline Item & Holstein milk & Yak milk \\
\hline Fat $(\%, w t / w t)$ & $3.56 \pm 0.47^{\mathrm{a}}$ & $6.72 \pm 0.23^{b}$ \\
\hline Protein $(\%, \mathrm{wt} / \mathrm{wt})$ & $3.13 \pm 0.28^{\mathrm{a}}$ & $5.28 \pm 0.43^{\mathrm{b}}$ \\
\hline Lactose $(\%, \mathrm{wt} / \mathrm{wt})$ & $3.91 \pm 0.18^{\mathrm{a}}$ & $5.01 \pm 0.26^{\mathrm{b}}$ \\
\hline $\operatorname{SNF}(\%, w t / w t)$ & $8.27 \pm 0.18^{\mathrm{a}}$ & $12.11 \pm 0.27^{\mathrm{b}}$ \\
\hline $\operatorname{Ash}(\mathrm{g} / \mathrm{kg})$ & $59.44 \pm 0.91^{\mathrm{a}}$ & $72.53 \pm 1.77^{\mathrm{b}}$ \\
\hline Casein (g/kg) & $23.8 \pm 2.2^{\mathrm{a}}$ & $41.6 \pm 3.5^{\mathrm{b}}$ \\
\hline$\alpha-\mathrm{CN}(\mathrm{g} / \mathrm{kg})$ & $11.41 \pm 2.15^{\mathrm{a}}$ & $11.98 \pm 3.07^{\mathrm{a}}$ \\
\hline$\beta-\mathrm{CN}(\mathrm{g} / \mathrm{kg})$ & $11.05 \pm 2.16^{\mathrm{a}}$ & $13.5 \pm 3.12^{\mathrm{a}}$ \\
\hline$\kappa-\mathrm{CN}(\mathrm{g} / \mathrm{kg})$ & $4.31 \pm 0.35^{\mathrm{b}}$ & $3.93 \pm 0.24^{\mathrm{a}}$ \\
\hline$\alpha-\mathrm{LA}(\mathrm{g} / \mathrm{kg})$ & $1.39 \pm 0.38^{\mathrm{a}}$ & $1.57 \pm 0.21^{\mathrm{b}}$ \\
\hline$\beta-\mathrm{LG}(\mathrm{g} / \mathrm{kg})$ & $4.91 \pm 0.92^{\mathrm{a}}$ & $5.33 \pm 0.92^{b}$ \\
\hline $\mathrm{Mg}(\mathrm{mg} / \mathrm{kg})$ & $109 \pm 6^{\mathrm{b}}$ & $85 \pm 4^{\mathrm{a}}$ \\
\hline $\mathrm{Ca}(\mathrm{mg} / \mathrm{kg})$ & $1,260 \pm 144^{\mathrm{a}}$ & $2,080 \pm 390^{\mathrm{b}}$ \\
\hline $\mathrm{K}(\mathrm{mg} / \mathrm{kg})$ & $744 \pm 32^{\mathrm{a}}$ & $1,512 \pm 28^{\mathrm{b}}$ \\
\hline $\mathrm{Na}(\mathrm{mg} / \mathrm{kg})$ & $341 \pm 35^{\mathrm{b}}$ & $285 \pm 22^{\mathrm{a}}$ \\
\hline $\mathrm{P}(\mathrm{mg} / \mathrm{kg})$ & $1,020 \pm 11^{\mathrm{a}}$ & $1,640 \pm 8^{\mathrm{b}}$ \\
\hline $\mathrm{RCT}(\mathrm{min})$ & $28.49 \pm 5.01^{\mathrm{a}}$ & $31.16 \pm 4.53$ \\
\hline $\mathrm{K} 20(\min )^{\prime}$ & $12.64 \pm 2.27^{\mathrm{b}}$ & $11.55 \pm 3.03^{\mathrm{a}}$ \\
\hline $\mathrm{A} 60(\mathrm{~mm})$ & $48.67 \pm 4.36^{\mathrm{a}}$ & $53.56 \pm 8.62^{\mathrm{b}}$ \\
\hline
\end{tabular}

a,b Means within a row with different superscripts are significantly different $(P<0.05)$. 

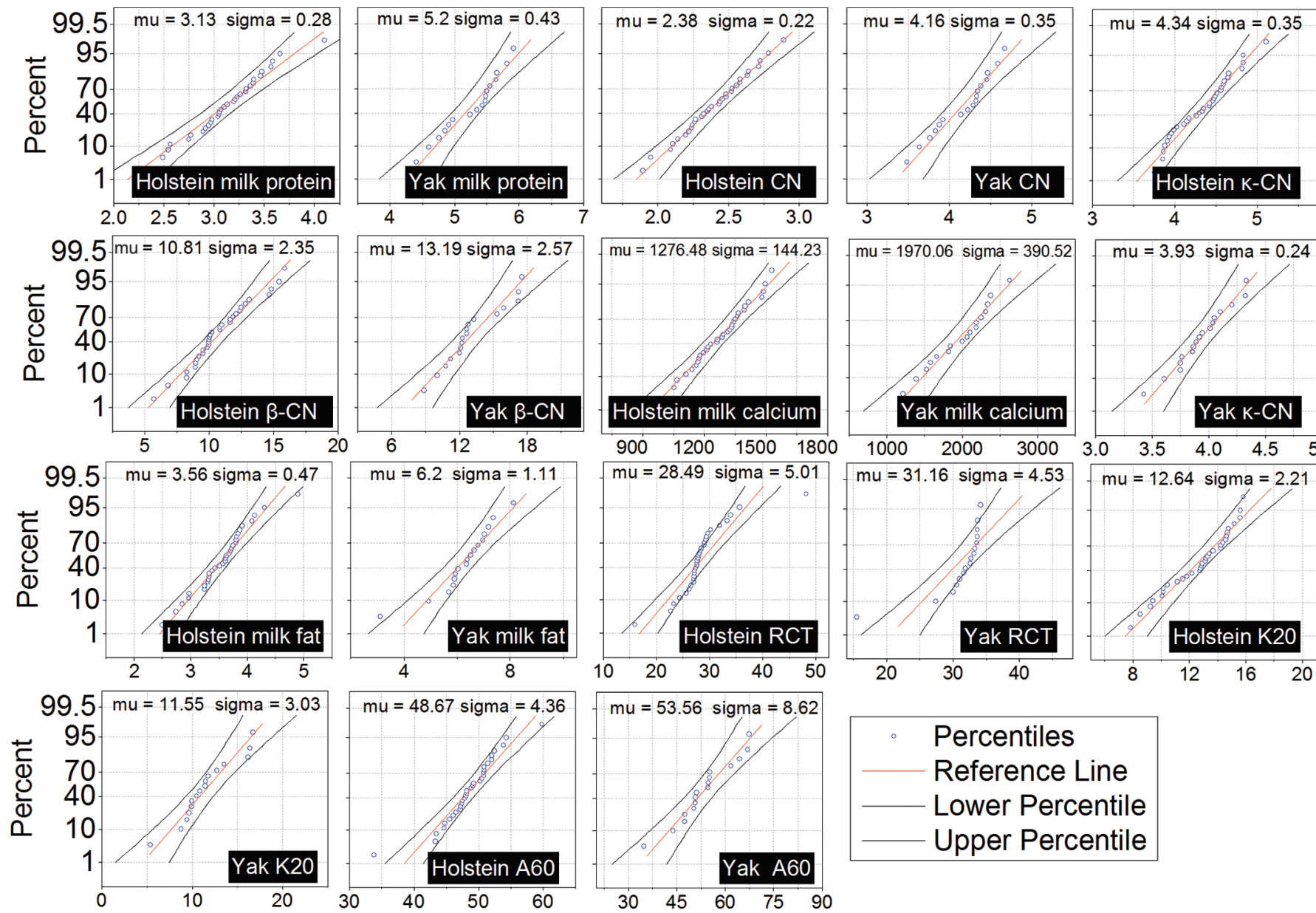

Figure 2. Normal probability plots of milk components and coagulation parameters of yak and Holstein milk, including protein, casein (CN), $\kappa-\mathrm{CN}, \beta-\mathrm{CN}$, fat, rennet coagulation time (RCT), rate of curd formation (K20), and curd firmness at 60 min (A60).

yak, based on phylogenetic analysis (Syed-Shabthar et al., 2013). Similar to our aforementioned findings in the coagulation properties of yak milk, milk from Jersey dairy cows also possessed longer RCT but faster rate of curd formation and firmer curd than Holstein milk (Auldist et al., 2004). This has been attributed to high concentrations of fat, protein, and total casein, and to the large size of paracaseins in Jersey milk that increase collision and formation of curd (Auldist et al., 2004).

\section{Correlation Analysis Between Milk Composition and MCP of Holstein and Yak Milk}

To analyze the correlation between the composition (fat, protein, total caseins, $\kappa$-caseins, $\beta$-caseins, and $\mathrm{Ca}^{2+}$ ) of yak milk with its MCP (RCT, K20, and A60), we first examined the normality of the data, using a normal probability plot to confirm that the data satisfied the prerequisite for Pearson correlation analysis.
As shown in Figure 2, most of the data followed a normal distribution, except that the RCT of both yak and Holstein milk were distributed in a non-normal pattern at the 0.05 significance level, due to 3 outliers. To address this non-normality, the outliers were removed, rendering all data suitable for Pearson correlation.

No correlation between milk components and RCT was observed in the analysis of all the samples from yak and Holstein cows (Table 2). For cows, many studies have also demonstrated poor correlations between RCT and milk components (Visentin et al., 2016; Nilsson et al., 2019), unlike goat milk, in which RCT is strongly correlated with fat and protein components (Stocco et al., 2018; Vacca et al., 2019). In our study, K20 and A60 were correlated with nearly every milk component measured, particularly with the concentrations of protein, calcium, casein, and fat. Despite these correlations, only a small amount of the total variation in milk coagulation characteristics was explained 
Table 2. Correlations between coagulation parameters and milk components for milk from yaks and Holstein cows ${ }^{1}$

\begin{tabular}{|c|c|c|c|c|c|c|c|c|c|c|c|c|}
\hline \multirow{3}{*}{$\begin{array}{l}\text { Milk } \\
\text { component }\end{array}$} & \multicolumn{6}{|c|}{ Holstein milk } & \multicolumn{6}{|c|}{ Yak milk } \\
\hline & \multicolumn{2}{|c|}{$\mathrm{RCT}$} & \multicolumn{2}{|c|}{ K20 } & \multicolumn{2}{|c|}{ A60 } & \multicolumn{2}{|c|}{$\mathrm{RCT}$} & \multicolumn{2}{|c|}{ K20 } & \multicolumn{2}{|c|}{$\mathrm{A} 60$} \\
\hline & $\mathrm{r}$ & $P$ & $\mathrm{r}$ & $P$ & $\mathrm{r}$ & $P$ & $\mathrm{r}$ & $P$ & $\mathrm{r}$ & $P$ & $\mathrm{r}$ & $P$ \\
\hline Protein & 0.47 & $\mathrm{NS}^{4}$ & -0.32 & $*$ & 0.30 & NS & 0.25 & $\mathrm{NS}$ & -0.48 & $* *$ & 0.54 & $* *$ \\
\hline Fat & 0.36 & NS & -0.13 & NS & 0.29 & $*$ & 0.20 & NS & -0.28 & $* *$ & 0.43 & $*$ \\
\hline Casein & 0.51 & NS & -0.57 & $*$ & 0.39 & $*$ & 0.19 & $\mathrm{NS}$ & -0.54 & $* *$ & 0.53 & $* *$ \\
\hline Calcium & 0.33 & NS & -0.23 & * & 0.39 & $*$ & 0.51 & NS & -0.63 & $* *$ & 0.72 & $* *$ \\
\hline
\end{tabular}

${ }^{1} \mathrm{RCT}=$ rennet coagulation time; K20 = rate of curd formation; A60 = curd firmness at 60 min.

${ }^{*} P<0.05 ;{ }^{* *} P<0.01$

by milk composition, as indicated by the correlation coefficients, $\mathrm{r}<0.50$. In the yak milk components, the calcium concentration correlated very well with K20 $(\mathrm{r}=-0.63, P<0.01)$ and $\mathrm{A} 60(\mathrm{r}=0.72, P<0.01)$. However, in Holstein milk, K20 $(\mathrm{r}=-0.23, P<0.05)$ and A60 ( $\mathrm{r}=0.39, P<0.05)$ were not well explained by the calcium concentration. This indicated that yak milk might be more sensitive to calcium concentrations, on coagulation, than Holstein milk is. Therefore, $\mathrm{CaCl}_{2}$ could be added to yak milk to improve its coagulation properties, just as Holsten milk has $\mathrm{CaCl}_{2}$ added before chymosin addition, for improvement of MCP (Fox et al., 2017a). However, variation of RCT of yak and Holstein milk could not be explained by the concentrations of $\kappa$-casein.

\section{Analysis of Chymosin-Induced Coagulation Using DLS}

To investigate the effects of size of casein micelles on MCP, we separated the caseins from yak and Holstein milk and monitored the hydrodynamic radius changes of the caseins during chymosin-induced coagulation using DLS. First, DLS tests of the chymosin-induced casein coagulation in $0.01 \mathrm{M}$ PBS were performed, to determine the applicability of the fast and slow modes in this system. The concentrations of casein were adjusted to $1.0 \mathrm{~g} / \mathrm{L}, 1.5 \mathrm{~g} / \mathrm{L}$, and $2.0 \mathrm{~g} / \mathrm{L}$, respectively, and chymosin was adjusted to $50 \mathrm{mg} / \mathrm{L}$, to prepare the clear transparent solutions for examination, and all DLS experiments were performed at scattering angle $90^{\circ}$, temperature $25^{\circ} \mathrm{C}$. Figure 3 shows 3 DLS autocorrelation functions and the results of the CONTIN analysis using fast and slow modes. The 2 overlapping peaks in the hydrodynamic time distributions indicated different relaxation time scales for the fast and slow modes. The autocorrelation curve of the fast mode that was performed in $100 \mathrm{~s}$ could be attributed to the initial phase of chymosin-induced coagulation, whereas the autocorrelation curve of slow mode $(1,000 \mathrm{~s})$ could be attributed to the further aggregation of caseins. These results suggested that DLS was suitable for measurement of the chymosin-induced coagulation of casein micelles.

Using the Stokes-Einstein equation and CONTIN analysis, we calculated the apparent average hydrodynamic radius $\left[\left(R_{h}\right)_{\text {app }}\right]$ and distributions $\left[f\left(R_{h}\right.\right.$, app $\left.)\right]$ of the yak and Holstein casein micelles and their para-CN micelles (Figure 4a, b). A similarity appeared in the curves of $f\left(R_{h}\right)$ of different samples, indicating that the distributions had regularity in all samples. Figure $4 \mathrm{a}$ shows that the calculated $\left(R_{h}\right)_{\text {app }}$ values for Holstein and yak casein micelles ranged from 91 to $367 \mathrm{~nm}$ and 116 to $516 \mathrm{~nm}$, respectively. Figure 4b shows, after adding $50 \mathrm{mg} / \mathrm{L}$ chymosin for $10 \mathrm{~min}$, the Z-average $\left(R_{h}\right)_{\text {app }}$ of chymosin, caseinomacropeptide, caseins, and paracaseins. The Z-average $\left(R_{h}\right)_{\text {app }}$ of chymosin and caseinomacropeptide of yak and Holstein milks were similar, about $2.08 \mathrm{~nm}$ and $16.71 \mathrm{~nm}$, respectively, whereas the Z-average $\left(R_{h}\right)_{\text {app }}$ of yak para-CN was $1620 \mathrm{~nm}$, twice that of the Holstein milk (789 nm). This size difference explains the MCP difference between yak and Holstein milk, as large casein micelles coagulate faster, resulting in a stronger gel than small casein micelles (Priyashantha et al., 2019). By applying this theory, mixing Jersey milk with Holstein milk has been found to increase the milk particle size (size of particles expressed as volume moment mean) of $\mathrm{D}(4.3), \mathrm{D}(3.2)$, and $\mathrm{D}(0.5)$, and to greatly improve the coagulation capacity of the resulting cheese milk (Bland et al., 2015). However, some reports indicate that small casein micelles coagulate faster to form firmer gel (Glantz et al., 2010; Logan et al., 2015). This might be due to the fact that milk with smaller casein micelles tends to contain a higher ratio of caseins, thus increasing its coagulation capacity (Day et al., 2015). 


\section{Effect of Calcium Concentration on Rheological Properties of Yak Curd}

To evaluate the influence of calcium concentration on the coagulation characteristics of yak milk, we compared the gelling processes of both yak and Holstein milk at $\mathrm{CaCl}_{2}$ concentrations of $0.015 \%, 0.02 \%$, and $0.03 \%$ (wt/wt) using optical microrheology, which continuously tracked the Brownian motion of particles to obtain MSD without affecting the gel structure. The MSD would grow linearly with decorrelation time in purely viscous samples with free movement of the particles, whereas the particles could be blocked by nearby particles or by polymer network interactions in viscoelastic samples (Ceniti et al., 2019). Typical MSD profiles compared with decorrelation time of our milk samples gelling at 0 and 40 min after chymosin addition are shown in Figure 5b. At the beginning of the gelling process (curves located in upper left corner of Figure 5b), MSD of all the samples gradually increased almost linearly with the decorrelation time, indicating the viscous properties of the samples of Holstein and yak milk at different $\mathrm{CaCl}_{2}$ concentrations at this stage. After addition of chymosin for $40 \mathrm{~min}$, the MSD was not linear and reached a plateau (curves located in lower right corner of Figure 5b), indicating the viscoelastic properties of the samples upon formation of gel networks. The curves of yak milk samples plateaued earlier, suggesting that yak milk formed gel faster (Sandra et al., 2012).

The elastic changes during 40-min coagulation are shown in Figure 5c. The climbing slopes of the curves for 3 yak milk samples were steeper and stabilized at the plateau region with higher elasticity due to rapid formation of firmer gel with yak milk. Sorted by the elasticity index values, the elasticity of $0.03 \% \mathrm{Ca}^{2+}$ yak milk $>0.02 \% \mathrm{Ca}^{2+}$ yak milk $>0.015 \% \mathrm{Ca}^{2+}$ yak milk $>$ $0.02 \% \mathrm{Ca}^{2+}$ Holstein milk $>0.015 \% \mathrm{Ca}^{2+}$ Holstein milk $>0.03 \% \mathrm{Ca}^{2+}$ Holstein milk $(P<0.05)$. This suggested that yak milk was more sensitive than Holstein milk to calcium concentration during the rennet coagulation process.

The SLB values, corresponding to the MSD slope at short decorrelation time, represent the ratio between solid-like and liquid-like behavior of the samples, with

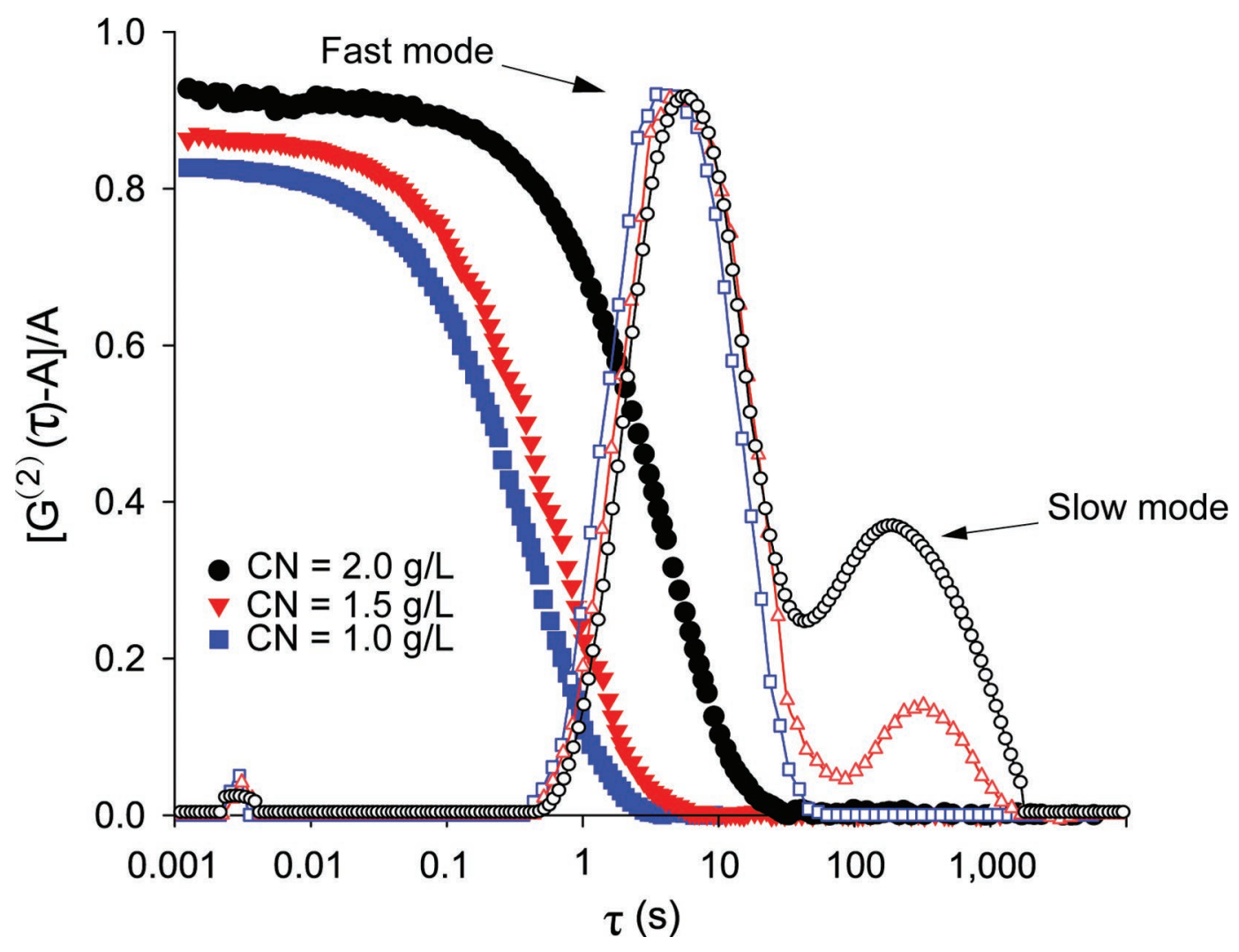

Figure 3. Typical autocorrelation function of the chymosin-induced casein (CN) micelle coagulation in $0.01 M$ PBS measured by dynamic light scattering (DLS) at concentrations of $1.0 \mathrm{~g} / \mathrm{L}(\mathbf{\square}), 1.5 \mathrm{~g} / \mathrm{L}(\mathbf{\nabla})$, and $2.0 \mathrm{~g} / \mathrm{L}(\mathbf{\bullet})$ at $25^{\circ} \mathrm{C}$, and the CONTIN inverse Laplace transforms of the DLS correlation functions $\left[\mathrm{G}^{(2)}(\tau)-\mathrm{A}\right] / \mathrm{A}$, corresponding to the hydrodynamic time distribution; open dots are a CONTIN analysis (scattering angle $\theta$ at $90^{\circ}$ ). 

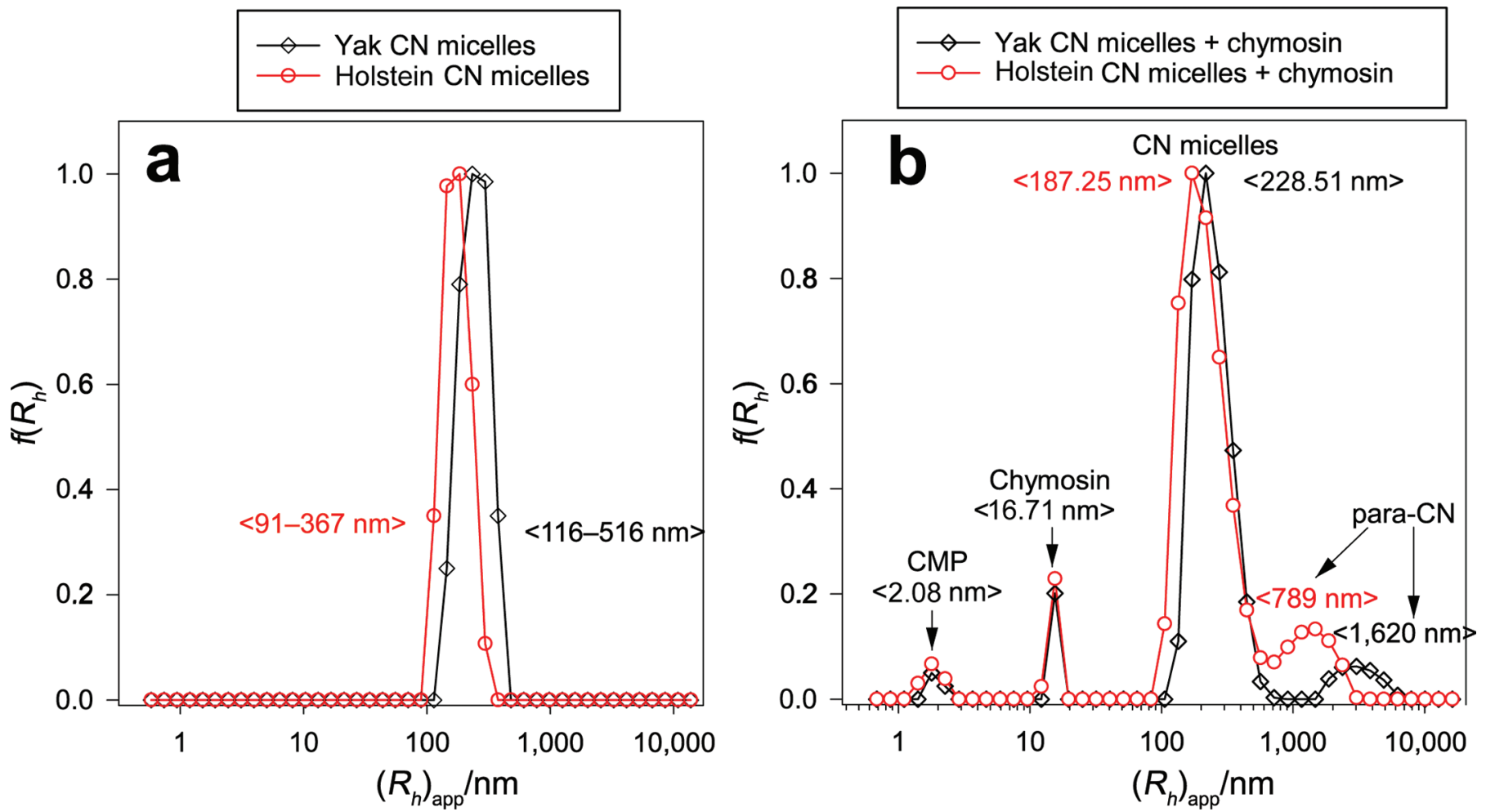

Figure 4. Dynamic light scattering (DLS) analysis of the sizes of casein (CN) micelles and paracaseins (para-CN). (a) Corresponding hydrodynamic radius distributions of yak and Holstein $\mathrm{CN}$ micelles at the concentration of $2 \mathrm{~g} / \mathrm{L}$; (b) corresponding hydrodynamic radius distributions of the particles in the mixture of chymosin $(50 \mathrm{mg} / \mathrm{L})$ and $\mathrm{CN}(2 \mathrm{~g} / \mathrm{L})$ solution, including CN micelles, caseinomacropeptide (CMP), and para-CN. These corresponding hydrodynamic radius distributions were calculated from CONTIN analysis.

$\mathrm{SLB}=0.5$ meaning that liquid and solid parts are equal, $0.5<\mathrm{SLB}<1$ indicating dominant liquid behavior, and $0<\mathrm{SLB}<0.5$ indicating dominant solid behavior (Xu et al., 2016). In this study, the decreasing trend of the SLB curves of all the samples confirmed the transitions of the samples from liquid to solid behavior during the coagulation process (Figure $5 \mathrm{~d}$ ). At the initial stage of the coagulation process, SLB values ranged from 0.65 to 0.82 , indicating dominant liquid behavior, and yak milk had lower values than did Holstein milk, indicating more solid behavior of yak milk. After 15 to $20 \mathrm{~min}$, the SLB values decreased to lower than 0.5 , indicating that the milk had started to coagulate. At the end of the coagulation process (40 min), SLB values (lower than 0.4) tended to be stable, and all samples had coagulated into solid curd. In the yak milk sample with higher calcium concentration of $0.03 \%$ (wt/wt), strong contraction of the curd was observed (Figure 5a). Similar gelling characteristics of yak casein micelles were also reported earlier (Zhang et al., 2017a). Overall, our results showed that yak milk could form the curd faster and with stronger texture than Holstein milk at the same calcium concentration, and it is suitable for cheese making.

\section{Comparison of Cheese Yields from Yak and Holstein Milk}

After cheese had ripened for 3 mo, we determined the cheese yields and physicochemical parameters. As shown in Table 3, the cheese yield from yak milk $(13.85 \%)$ was 1.67 -fold that of Holstein milk $(8.28 \%$; $P$ $<0.05)$, and the yak cheese yield was also higher than that of previously reported Jersey milk (12.8\%; Bland et al., 2015) but lower than that of white yak milk (15.5\%; Liu et al., 2009). The high cheese yield of yak milk was consistent with the results of MCP analysis of this study. The fat and moisture contents of yak Cheddar were also higher than those of Holstein Cheddar cheese. This could be explained by Walstra's research, that large fat globules result in more moisture retention during curd pressing (Walstra et al., 2005).

\section{Comparison of Texture and Microstructural Properties of Cheeses from Yak and Holstein Milk}

Texture is an important profile of cheese quality, and it closely relates to the composition and processing method of cheese (Fox et al., 2017b). Because the 
composition of Cheddar cheeses made from yak and Holstein milk was different, we further examined the texture and microstructural properties of the cheeses.

The flowability of the heated cheeses increased significantly during the 3-mo aging process (Figure 6a). The yak Cheddar cheese showed a higher flowability than did the Holstein Cheddar, due to the higher fat content of the former, a driving force in cheese melting (Lefevere et al., 2000). As the aging process extended, the difference in cheese flowability between the cheese from the 2 species became narrower $(P<0.05)$. We further examined the changes in cheese moisture during the aging process, and found no significant correlations between the moisture difference with the flow rate difference between the cheeses of the 2 species $\left(\mathrm{R}^{2}=0.415\right.$, $P=0.14)$. So the narrowing tendency of the flowability between the 2 groups of cheese could be attributed to the different extents of protein and fat hydrolysis during cheese ripening (McCarthy et al., 2017). The hardness and fraction force of yak Cheddar cheese were
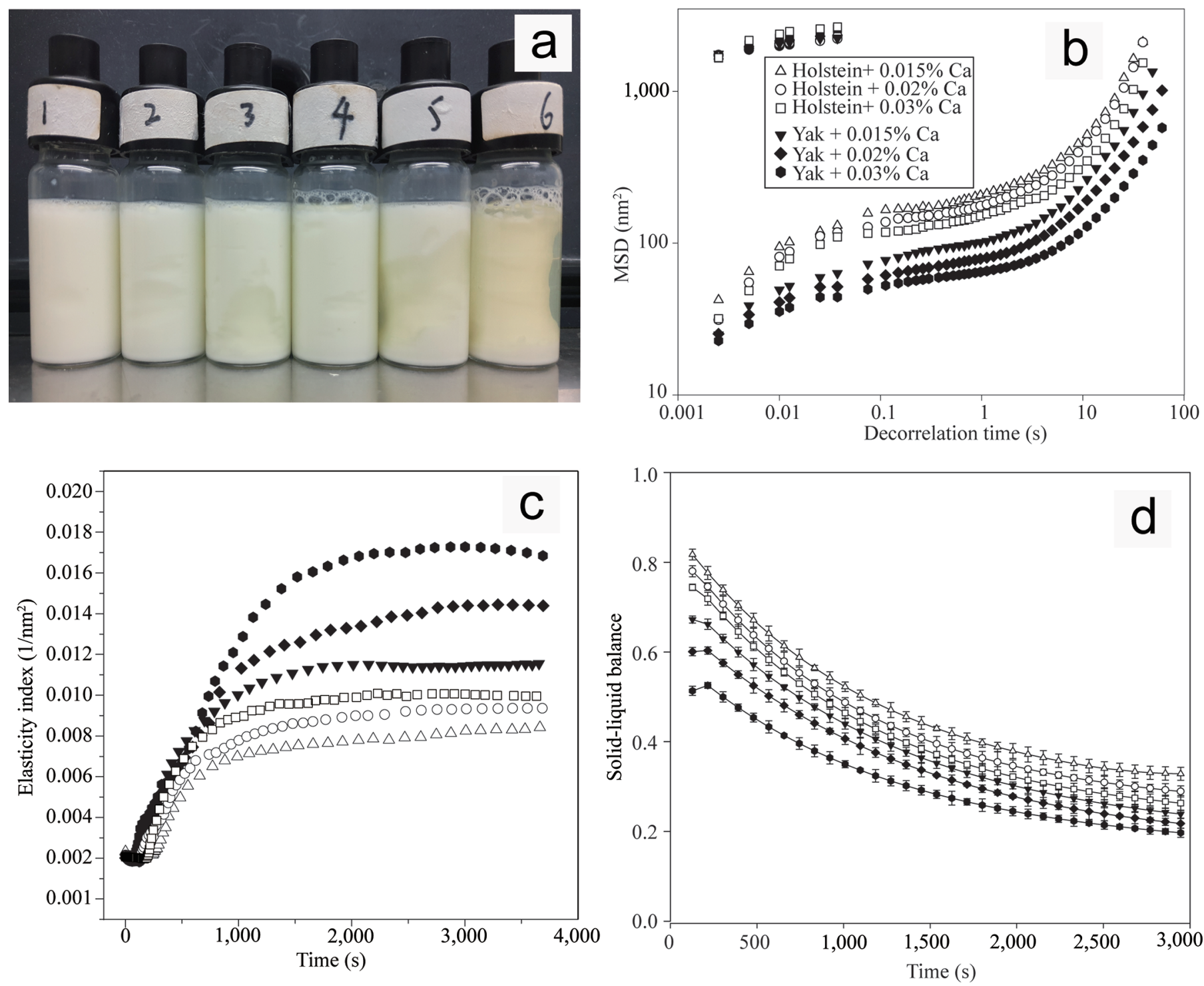

Figure 5. Microrheology of milk with different concentrations of $\mathrm{Ca}^{2+}$. (a) Sample bottles: $1=$ Holstein milk with $0.015 \%$ (wt/wt) $\mathrm{CaCl}_{2} ; 2=$ Holstein milk with $0.02 \%$ (wt/wt) $\mathrm{CaCl}_{2} ; 3=$ Holstein milk with $0.03 \%$ (wt/wt) $\mathrm{CaCl}_{2} ; 4=$ yak milk with $0.015 \%$ (wt/wt) $\mathrm{CaCl} 2 ; 5=$ yak milk with $0.02 \%$ (wt/wt) $\mathrm{CaCl}_{2} ; 6$ = yak milk with $0.03 \%$ (wt/wt) $\mathrm{CaCl}_{2}$. (b) Mean square displacement (MSD) immediately after chymosin addition (curves in the upper left corner) and after $40 \mathrm{~min}$ (curves in the lower part). (c) Elasticity change of the samples during 60-min coagulation. (d) Solid-liquid balance $\left(1 / \mathrm{nm}^{2}\right)$ of the samples during 40-min coagulation. Error bars represent SD of the means. 
Table 3. Composition of Holstein and yak milk, and yield and composition of Cheddar cheeses made from Holstein and yak milk ${ }^{1}$

\begin{tabular}{lccrc}
\hline Item & Holstein milk & Yak milk & Holstein milk cheese & Yak milk cheese \\
\hline Yield (\%) & - & - & $8.28 \pm 0.15^{\mathrm{a}}$ & $13.85 \pm 0.12^{\mathrm{b}}$ \\
Protein (\%) & $3.28 \pm 0.18^{\mathrm{a}}$ & $4.31 \pm 0.25^{\mathrm{b}}$ & $24.12 \pm 0.27^{\mathrm{b}}$ & $22.51 \pm 0.31^{\mathrm{a}}$ \\
Fat (\%) & $3.55 \pm 0.33^{\mathrm{a}}$ & $5.22 \pm 0.22^{\mathrm{b}}$ & $28.57 \pm 1.12^{\mathrm{a}}$ & $32.05 \pm 0.59^{\mathrm{b}}$ \\
Lactose (\%) & $4.01 \pm 0.11^{\mathrm{a}}$ & $4.55 \pm 0.12^{\mathrm{b}}$ & $51.24 \pm 0.64^{\mathrm{a}}$ & $54.24 \pm 0.72^{\mathrm{b}}$ \\
FDM (\%) & - & - & $3.90 \pm 0.14^{\mathrm{a}}$ & $3.72 \pm 0.38^{\mathrm{a}}$ \\
Salt (\%, wt/wt) & - & - & $29.57 \pm 0.01^{\mathrm{a}}$ & $31.28 \pm 0.67^{\mathrm{b}}$ \\
Moisture (\%,wt/wt) & $6.68 \pm 0.07^{\mathrm{a}}$ & $6.61 \pm 0.19^{\mathrm{a}}$ & $3.0 .05^{\mathrm{a}}$ & $5.45 \pm 0.02^{\mathrm{a}}$ \\
pH & - & - & $3.91 \pm 0.04^{\mathrm{a}}$ & $4.38 \pm 0.01^{\mathrm{b}}$ \\
Ash (\%) & &
\end{tabular}

$\overline{\mathrm{a}, \mathrm{b}}$ Means within a row with different superscripts differ $(P<0.05)$.

1 - not measured; FDM $=$ fat in dry matter.

higher than those of Holstein Cheddar (Figure 6b, c), and during aging, both the hardness and the fraction force of cheeses from the 2 species decreased gradually in a similar pattern.

The microstructures of yak and Holstein Cheddar cheeses were observed via scanning electron microscope at $10-\mu \mathrm{m}$ and $50-\mu \mathrm{m}$ scales. At the scale of $50 \mu \mathrm{m}$, the yak cheese (Figure 7B) showed a denser and uniformed gel network with smaller pores than the Holstein milk cheese (Figure 7A). Previously, yak casein micelles were shown to form tightly packed gels, whereas Holstein casein micelles formed loosely packed gels (Zhang et al., 2017a). At the scale of $10 \mu \mathrm{m}$, the yak cheese (Figure $7 \mathrm{~b}$ ) showed a continuous and smooth surface, whereas the Holstein cheese was full of cracks and even the boundaries between the gel granules could be discriminated. These explained the higher hardness and fraction force of yak Cheddar cheese observed in this study.

\section{CONCLUSIONS}

Compositional comparison of milk from 32 individual Holstein cows and 17 yak cows showed generally higher concentrations of milk components in yak milk. The concentrations of fat, protein, SNF, and calcium in yak milk were 1.89-, 1.68-, 1.46-, and 2-fold those in Holstein milk. A DLS analysis showed larger hydrodynamic radii of casein micelles $(187.25 \mathrm{~nm})$ and paracasein $(1,620$ $\mathrm{nm}$ ) in yak milk. Correlation analysis suggested that higher concentration of calcium in yak milk, together with larger size of casein micelles, could explain the faster rate of curd formation and firmer curd of yak milk. Optical microrheology analysis showed that chymosin-induced coagulation of yak milk was more sensitive to the concentration of $\mathrm{Ca}^{2+}$ than was that of Holstein milk. Cheese making trials with yak and Holstein milk proved the higher cheese yield of yak milk,
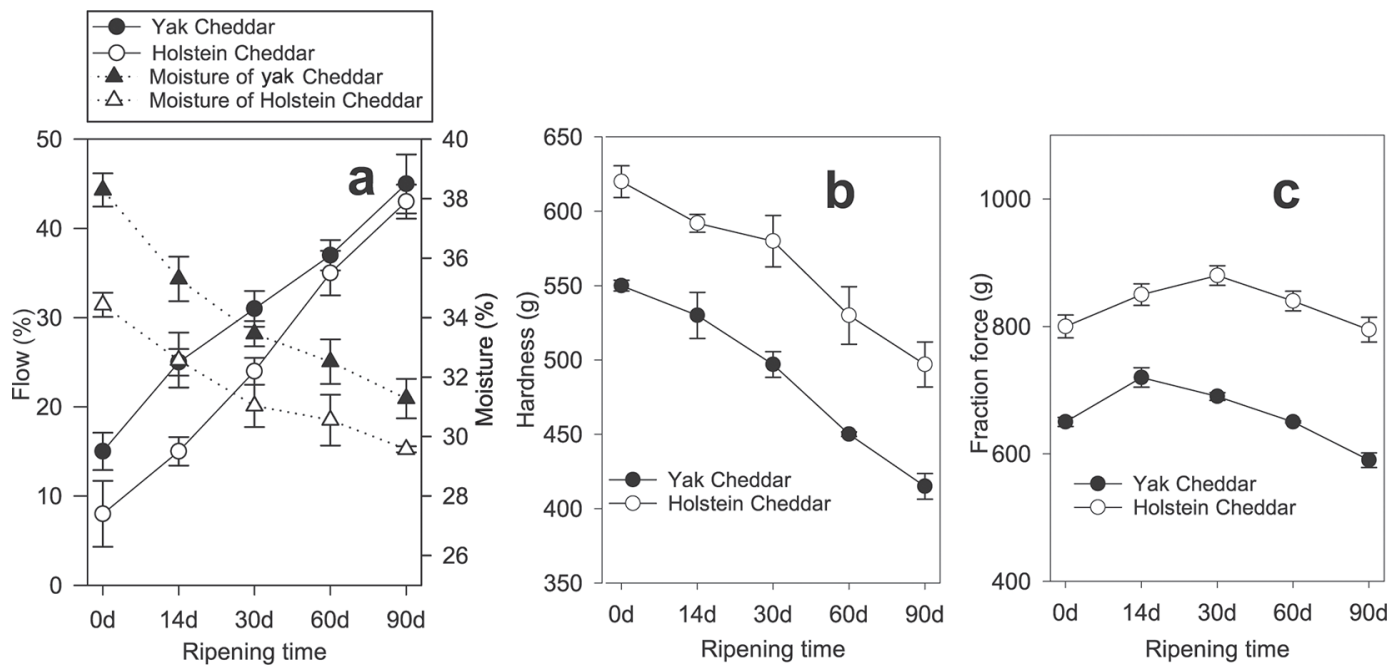

Figure 6. Extent of flow upon heating and moisture (a). Hardness (b) and fraction force (c) during 3-mo ripening of Holstein and yak milkbased Cheddar cheeses. Values were measured across 3 replicate trials; error bars represent SD of the means. 

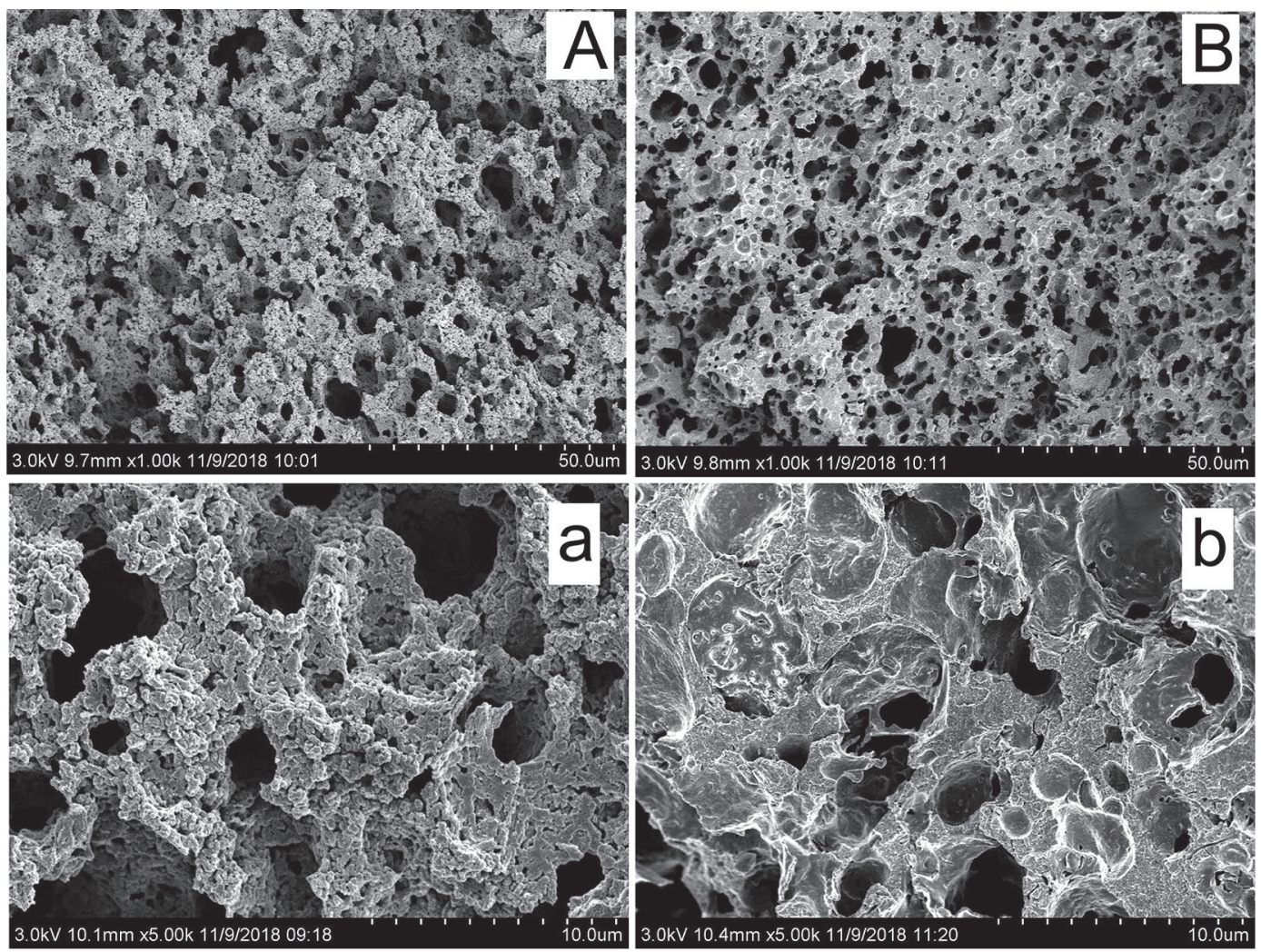

Figure 7. Cryoscanning electron microscopy images of Holstein Cheddar cheese (A) and yak Cheddar cheese (B) at 50- $\mu \mathrm{m}$ scale; Holstein cheese (a) and yak cheese (b) at 10- $\mu$ m scale.

1.67-fold that of Holstein milk. Therefore, yak milk is a suitable source of milk for enzyme-coagulated cheese making.

\section{ACKNOWLEDGMENTS}

Financial support from Beijing Municipal Natural Science Foundation (6192004), National Natural Science Foundation of China (31571857; Beijing), Beijing Talent Cultivation Quality Construction - First-class Professional Construction (Municipal Level) - Food Science and Engineering (PXM2019_014213_000010), 2019 Postgraduate Research Capacity Improvement Program (19008001616), and 2019 Basic Research Project - Food Special Project (PXM2019_014213_000007), is gratefully acknowledged. The authors have not stated any conflicts of interest.

\section{REFERENCES}

Akkerman, M., L. B. Larsen, J. Sørensen, and N. A. Poulsen. 2019. Natural variations of citrate and calcium in milk and their effects on milk processing properties. J. Dairy Sci. 102:6830-6841. https: //doi.org/10.3168/jds.2018-16195.
Auldist, M. J., K. A. Johnston, N. J. White, W. P. Fitzsimons, and M. J. Boland. 2004. A comparison of the composition, coagulation characteristics and cheesemaking capacity of milk from Friesian and Jersey dairy cows. J. Dairy Res. 71:51-57. https://doi.org/10 $.1017 / \mathrm{s} 0022029903006575$.

Bland, J. H., A. S. Grandison, and C. C. Fagan. 2015. Effect of blending Jersey and Holstein-Friesian milk on Cheddar cheese processing, composition, and quality. J. Dairy Sci. 98:1-8. https://doi .org/10.3168/jds.2014-8433.

Bonfatti, V., L. Degano, A. Menegoz, and P. Carnier. 2016. Short communication: Mid-infrared spectroscopy prediction of fine milk composition and technological properties in Italian Simmental. J. Dairy Sci. 99:8216-8221. https://doi.org/10.3168/jds.2016-10953.

Buhler, E., and M. Rinaudo. 2000. Structural and dynamical properties of semirigid polyelectrolyte solutions: A light-scattering study. Macromolecules 33:2098-2106. https://doi.org/10.1021/ ma991309+.

Ceniti, C., F. Froiio, D. Britti, D. Paolino, and N. Costanzo. 2019. Rheological characteristics of bovine colostrum and their correlation with immunoglobulin G. Int. J. Dairy Technol. 1471-0307.12593. https://doi.org/10.1111/1471-0307.12593.

Cui, G. X., F. Yuan, A. A. Degen, S. M. Liu, J. W. Zhou, Z. H. Shang, L. M. Ding, J. D. Mi, X. H. Wei, and R. J. Long. 2016. Composition of the milk of yaks raised at different altitudes on the QinghaiTibetan Plateau. Int. Dairy J. 59:29-35. https://doi.org/10.1016/ j.idairyj.2016.02.046.

Day, L., R. P. W. Williams, D. Otter, and M. A. Augustin. 2015. Casein polymorphism heterogeneity influences casein micelle size in milk of individual cows. J. Dairy Sci. 98:3633-3644. https://doi .org/10.3168/jds.2014-9285. 
De Marchi, M., R. Dal Zotto, M. Cassandro, and G. Bittante. 2007. Milk coagulation ability of five dairy cattle breeds. J. Dairy Sci. 90:3986-3992. https://doi.org/10.3168/jds.2006-627.

Fox, P. F., T. P. Guinee, T. M. Cogan, and P. L. H. McSweeney. 2017a. Enzymatic coagulation of milk. Pages 185-229 in Fundamentals of Cheese Science. P. F. Fox, T. P. Guinee, T. M. Cogan, and P. L. H. McSweeney, ed. Springer, Boston, MA.

Fox, P. F., T. P. Guinee, T. M. Cogan, and P. L. H. McSweeney. 2017b. Cheese: structure, rheology and texture. Pages 475-532 in Fundamentals of Cheese Science. P. F. Fox, T. P. Guinee, T. M. Cogan, and P. L. H. McSweeney, ed. Springer, Boston, MA.

Glantz, M., T. G. Devold, G. E. Vegarud, H. Lindmark Månsson, H. Stålhammar, and M. Paulsson. 2010. Importance of casein micelle size and milk composition for milk gelation. J. Dairy Sci. 93:14441451. https://doi.org/10.3168/jds.2009-2856.

Hickey, D. K., K. N. Kilcawley, T. P. Beresford, E. M. Sheehan, and M. G. Wilkinson. 2006. The influence of a seasonal milk supply on the biochemical and sensory properties of Cheddar cheese. Int. Dairy J. 16:679-690. https://doi.org/10.1016/j.idairyj.2005.10.017.

Lefevere, I., K. Dewettinck, and A. Huyghebaert. 2000. Cheese fat as driving force in cheese flow upon melting. Milchwissenschaft 55:563-566.

Lehmann, M., W. Tabaka, T. Moller, A. Oppermann, D. Woll, D. Volodkin, S. Wellert, and R. V. Klitzing. 2018. DLS setup for in situ measurements of photoinduced size changes of microgelbased hybrid particles. Langmuir 34:3597-3603. https://doi.org/ 10.1021/acs.langmuir.7b04298.

Li, H., Y. Ma, Q. Li, J. Wang, J. Cheng, J. Xue, and J. Shi. 2011. The chemical composition and nitrogen distribution of Chinese yak (Maiwa) milk. Int. J. Mol. Sci. 12:4885-4895. https://doi.org/ 10.3390/ijms12084885.

Lin, K., L. Zhang, X. Han, Z. Meng, J. Zhang, Y. Wu, and D. Cheng. 2018. Quantitative structure-activity relationship modeling coupled with molecular docking analysis in screening of angiotensin i-converting enzyme inhibitory peptides from Qula casein hydrolysates obtained by two-enzyme combination hydrolysis. J. AGR. J. Agric. Food Chem. 66:3221-3228. https://doi.org/10.1021/acs .jafc.8b00313.

Liu, X., B. Gan, F. Li, H. Qiao, J. Niu, and X. Song. 2009. Processing technology of hard cheese from milk of white yak. Food Science (China) 30:94-98.

Logan, A., A. Leis, L. Day, S. K. Øiseth, A. Puvanenthiran, and M. A. Augustin. 2015. Rennet gelation properties of milk: Influence of natural variation in milk fat globule size and casein micelle size. Int. Dairy J. 46:71-77. https://doi.org/10.1016/j.idairyj.2014 .08 .005 .

Logan, A., M. Xu, L. Day, T. Singh, S. C. Moore, M. Mazzonetto, and M. A. Augustin. 2017. Milk fat globule size affects Cheddar cheese properties. Int. Dairy J. 70:46-54. https://doi.org/10.1016/ j.idairyj.2016.11.003.

Luo, J., Z. Huang, H. Liu, Y. Zhang, and F. Ren. 2018. Yak milk fat globules from the Qinghai-Tibetan Plateau: Membrane lipid composition and morphological properties. Food Chem. 245:731-737. https://doi.org/10.1016/j.foodchem.2017.12.001.

Manderson, G. A., M. J. Hardman, and L. K. Creamer. 1998. Effect of heat treatment on the conformation and aggregation of $\beta$-Lactoglobulin A, B, and C. J. AGR. Food Chem. 46:5052-5061. https://doi.org/10.1021/jf980515y.

McCarthy, C. M., M. G. Wilkinson, and T. P. Guinee. 2017. Effect of coagulant type and level on the properties of half-salt, half-fat Cheddar cheese made with or without adjunct starter: Improving texture and functionality. Int. Dairy J. 75:30-40. https://doi.org/ 10.1016/j.idairyj.2017.07.006.

McCarthy, C. M., M. G. Wilkinson, P. M. Kelly, and T. P. Guinee. 2016. Effect of salt and fat reduction on proteolysis, rheology and cooking properties of Cheddar cheese. Int. Dairy J. 56:74-86. https://doi.org/10.1016/j.idairyj.2016.01.001.

Murphy, S. C., N. H. Martin, D. M. Barbano, and M. Wiedmann. 2016. Influence of raw milk quality on processed dairy products: How do raw milk quality test results relate to product quality and yield? J. Dairy Sci. 99:10128-10149. https://doi.org/10.3168/jds .2016-11172.

Nilsson, K., H. Stålhammar, M. Stenholdt Hansen, H. LindmarkMånsson, S. Duchemin, F. Fikse, D. J. de Koning, M. Paulsson, and M. Glantz. 2019. Characterisation of non-coagulating milk and effects of milk composition and physical properties on rennetinduced coagulation in Swedish Red Dairy Cattle. Int. Dairy J. 95:50-57. https://doi.org/10.1016/j.idairyj.2019.03.006.

Or-Rashid, M. M., N. E. Odongo, B. Subedi, P. Karki, and B. W. McBride. 2008. Fatty acid composition of yak (Bos grunniens) cheese including conjugated linoleic acid and trans-18:1 fatty acids. J. Agric. Food Chem. 56:1654-1660. https://doi.org/10.1021/jf0725225.

Priyashantha, H., Å. Lundh, A. Höjer, M. Hetta, M. Johansson, and M. Langton. 2019. Interactive effects of casein micelle size and calcium and citrate content on rennet-induced coagulation in bovine milk. J. Texture Stud. jtxs.12454. https://doi.org/10.1111/ jtxs. 12454

Sandra, S., C. Cooper, M. Alexander, and M. Corredig. 2011. Coagulation properties of ultrafiltered milk retentates measured using rheology and diffusing wave spectroscopy. Food Res. Int. 44:951-956. https://doi.org/10.1016/j.foodres.2011.02.018.

Sandra, S., M. Ho, M. Alexander, and M. Corredig. 2012. Effect of soluble calcium on the renneting properties of casein micelles as measured by rheology and diffusing wave spectroscopy. J. Dairy Sci. 95:75-82. https://doi.org/10.3168/jds.2011-4713.

Scotti, A., W. Liu, J. S. Hyatt, E. S. Herman, H. S. Choi, J. W. Kim, L. A. Lyon, U. Gasser, and A. Fernandez-Nieves. 2015. The CONTIN algorithm and its application to determine the size distribution of microgel suspensions. J. Chem. Phys. 142:234905. https:// doi.org/10.1063/1.4921686.

Stocco, G., C. Cipolat-Gotet, T. Bobbo, A. Cecchinato, and G. Bittante. 2017. Breed of cow and herd productivity affect milk composition and modeling of coagulation, curd firming, and syneresis. J. Dairy Sci. 100:129-145. https://doi.org/10.3168/jds.2016-11662.

Stocco, G., M. Pazzola, M. L. Dettori, P. Paschino, G. Bittante, and G. M. Vacca. 2018. Effect of composition on coagulation, curd firming, and syneresis of goat milk. J. Dairy Sci. 101:9693-9702. https://doi.org/10.3168/jds.2018-15027.

Sun, J., F. Ren, Y. Chang, P. Wang, Y. Li, H. Zhang, and J. Luo. 2018. Formation and structural properties of acid-induced caseinagar double networks: Role of gelation sequence. Food Hydrocolloids 85:291-298. https://doi.org/10.1016/j.foodhyd.2018.07.030.

Syed-Shabthar, S. M. F., M. K. A. Rosli, N. A. A. Mohd-Zin, S. M. N. Romaino, Z. A. Fazly-Ann, M. C. Mahani, O. Abas-Mazni, R. Zainuddin, S. Yaakop, and B. M. Md-Zain. 2013. The molecular phylogenetic signature of Bali cattle revealed by maternal and paternal markers. Mol. Biol. Rep. 40:5165-5176. https://doi.org/10 $.1007 / \mathrm{s} 11033-013-2619-\mathrm{y}$.

Vacca, G. M., C. Cipolat-Gotet, P. Paschino, S. Casu, M. G. Usai, G. Bittante, and M. Pazzola. 2019. Variation of milk technological properties in sheep milk: Relationships among composition, coagulation and cheese-making traits. Int. Dairy J. 97:5-14. https://doi .org/10.1016/j.idairyj.2019.05.002.

Visentin, G., M. Penasa, P. Gottardo, M. Cassandro, and M. De Marchi. 2016. Predictive ability of mid-infrared spectroscopy for major mineral composition and coagulation traits of bovine milk by using the uninformative variable selection algorithm. J. Dairy Sci. 99:8137-8145. https://doi.org/10.3168/jds.2016-11053.

Walstra, P., J. T. M. Wouters, and T. J. Geurts. 2005. Dairy Science and Technology. CRC Press, New York, NY.

Xu, D., Z. Aihemaiti, Y. Cao, C. Teng, and X. Li. 2016. Physicochemical stability, microrheological properties and microstructure of lutein emulsions stabilized by multilayer membranes consisting of whey protein isolate, flaxseed gum and chitosan. Food Chem. 202:156-164. https://doi.org/10.1016/j.foodchem.2016.01.052.

Yang, M., W. Zhang, P. Wen, Y. Zhang, and Q. Liang. 2014. Heat stability of yak micellar casein as affected by heat treatment temperature and duration. Dairy Sci. Technol. 94:469-481. https://doi .org/10.1007/s13594-014-0173-6. 
Zendri, F., M. Ramanzin, C. Cipolat-Gotet, and E. Sturaro. 2017. Variation of milk coagulation properties, cheese yield, and nutrients recovery in curd of cows of different breeds before, during and after transhumance to highland summer pastures. J. Dairy Res. 84:39-48. https://doi.org/10.1017/S0022029916000583.

Zhang, Y., Y. Li, P. Wang, Y. Tian, Q. Liang, and F. Ren. 2017a. Rennet-induced coagulation properties of yak casein micelles: A comparison with cow casein micelles. Food Res. Int. 102:25-31. https://doi.org/10.1016/j.foodres.2017.09.097.

Zhang, Y., S. Li, and L. Zhang. 2010. Aggregation behavior of triple helical polysaccharide with low molecular weight in diluted aqueous solution. J. Phys. Chem. B 114:4945-4954. https://doi.org/10 1021/jp9100398.

Zhang, L., X. Zhang, C. Liu, C. Li, S. Li, T. Li, D. Li, Y. Zhao, and Z. Yang. 2013. Manufacture of Cheddar cheese using probiotic Lactobacillus plantarum $\mathrm{K} 25$ and its cholesterol-lowering effects in a mice model. World J. Microbiol. Biotechnol. 29:127-135. https:// doi.org/10.1007/s11274-012-1165-4 https://xs.scihub.ltd/https:// doi.org/10.1007/s11274-012-1165-4.

Zhang, J., W. Zhao, X. Guo, T. Guo, Y. Zheng, Y. Wang, Y. Hao, and Z. Yang. 2017b. Survival and effect of exopolysaccharide-producing Lactobacillus plantarum YW11 on the physicochemical properties of ice cream. Pol. J. Food Nutr. Sci. 67:191-200. https://doi .org/10.1515/pjfns-2017-0002.

Zulewska, J., J. Kowalik, A. Lobacz, and B. Dec. 2018. Short communication: Calcium partitioning during microfiltration of milk and its influence on rennet coagulation time. J. Dairy Sci. 101:1086010865. https://doi.org/10.3168/jds.2018-14830.

\section{ORCIDS}

Jian Zhang (ํ) https://orcid.org/0000-0001-9745-3927

Zhennai Yang ำ https://orcid.org/0000-0001-5043-8260 